\title{
Serum Copper and Plasma Protein Status in Preterm Delivery
}

\author{
Masuda Sultana ${ }^{1}$, Nasim Jahan ${ }^{2}$, Nayma Sultana ${ }^{3}$, Rezina Akter $^{4}$
}

\begin{abstract}
Background: Preterm delivery is a major obstetric related problem in Bangladesh. Micronutrient deficiency especially deficiency of copper may affect pregnancy, delivery and outcome of pregnancy. Reduced serum copper concentration of the pregnant mother may have some role in resulting preterm delivery. Objectives: To observe serum $\mathrm{Cu}$ and protein status in preterm mother and their neonates. Methods: This cross sectional study was carried out in the Department of Physiology, Sir Salimullah Medical College and Mitford Hospital, Dhaka, between January and December 2009. A total number of 136 subjects were included in this study, and were divided into control $(n=82)$ and study $(n=54)$ groups. Of the control group, 28 were non pregnant women age ranged between 20-30 years, taken for reference value and another 54 were full term group, also treated as control, were sub-divided into normal full term mother $(n=27)$ and their respective neonates $(n=27)$. Another 54 were preterm group, considered as study group, were sub-divided into preterm mothers $(\mathrm{n}=27)$ and their respective neonates $(\mathrm{n}=27)$. Age of preterm and full term mothers were between $20-40$ years. All the subjects belonged to lower socioeconomic status. The pregnant women were selected from the labor ward of Sir Salimullah Medical College and Mitford Hospital and non pregnant women were from personal contact. Serum copper level was estimated by spectrophotometric method, to observe its level in these groups of study subjects. Serum total protein, albumin and globulin levels were estimated by usual laboratory technique in order to observe the availability of binding proteins as well as their nutritional status. Again, anthropometric data and blood hemoglobin level of the preterm and full term mother and birth weight of their respective neonates were measured to observe their nutritional status. Correlation of maternal serum copper concentration with that of neonatal blood and also with birth weight of the neonates were done to observe their relationship. Statistical analysis was done by Independent-Samples " $t$ " test and Peaeson's correlation coefficient tests as applicable. Results: Mean serum $\mathrm{Cu}$, total protein and albumin levels were significantly $(p<0.001)$ lower in preterm mother and their neonates in comparison to those of full term mother and their neonates respectively. Whereas, mean serum globulin level showed no statistically significant difference among the groups. Mean birth weight of preterm neonates was significantly lower in comparison to that of full term neonates. Again, maternal serum copper level showed negative correlation with that of neonatal blood but positive correlation with birth weight of their neonates in both full term and preterm mother, though these relationships were not statistically significant. Conclusions: The present study revealed hypocupremia and hypoproteinemia in pre-term delivery mother and their neonates. This hypocupremia may be due to poor maternal protein status.
\end{abstract}

Key Words: Copper, Protein, Preterm

J Bangladesh Soc Physiol. 2012 June; 7(1): 41-47 For Authors Affiliation, see end of text.

http://www.banglajol.info/index.php/JBSP

\section{Introduction}

$\mathbf{P}$

reterm delivery occurs after 26 weeks but before 37 weeks of gestation ${ }^{1}$. The rates of preterm delivery and low birth weight

Received February 2012; $\quad$ Accepted May 2012 neonate have increased in the recent years in spite of increasing antenatal care $^{2}$. Metabolic demand increases in pregnancy both for the mother and for the developing fetus ${ }^{3}$. Again, adequate maternal trace element is essential for

J Bangladesh Soc Physiol. 2012, June; 7(1): 41-47 
normal embryogenesis ${ }^{4}$. Micronutrient copper $(\mathrm{Cu})$ is important for normal fetal development ${ }^{5}$. It is essential for hemopoiesis and act as a cofactor for many enzymes such as cytochrome oxidase, mono-amine oxidase, ascorbic oxidase ${ }^{6}$. In developing countries $98 \%$ of preterm delivery occurs due to nutritional deficiency ${ }^{7}$. Inadequate dietary intake before and during pregnancy causes poor maternal nutritional status and restricted fetal growth. Micronutrient deficiency especially deficiency of copper $(\mathrm{Cu})$ during pregnancy strongly affect fetal growth as well as length of gestation ${ }^{8}$. It has also been reported that copper deficiency may cause premature birth and malnourished infants ${ }^{9}$. Deficiency of micronutrient causes a number of maternal and fetal complications during pregnancy and delivery ${ }^{10}$. Furthermore, different studies demonstrated that maternal micronutrient deficiency especially deficiency of copper may be responsible for the increased incidence and outcome of low birth weight infants ${ }^{11,12}$. Deficiency of copper may occur during pregnancy due to low estrogen level, low dietary intake and metabolic defect ${ }^{13}$.

Furthermore, other nutritional deficiencies such as deficiency of protein, vitamins etc. may also be responsible for preterm delivery especially in developing countries ${ }^{2}$. In addition to this, protein deficiency, especially deficiency of albumin and globulin may also be responsible for decreased maternal plasma $\mathrm{Cu}$ concentration, as they act as Cu-binding vehicle ${ }^{4,10}$.

So, pregnancy is often associated with increased demand of all the nutrients like iron, copper, zinc, proteins etc. and deficiency of one of these may affect pregnancies, delivery and outcome of pregnancy $^{13}$. Some studies have been done regarding this matter in abroad ${ }^{14,15}$. But little is known on this aspect in our country. For this, the present study was aimed at to observe serum $\mathrm{Cu}$ and protein levels in preterm delivery mother and their respective neonates. The output of the study may be helpful to create awareness about the deficiency of $\mathrm{Cu}$ and protein in preterm delivery mother with their respective neonates and to take appropriate measure for the improvement of pregnancy outcome by observing their status in pregnant women to prevent the risk of complication in pregnancy. Moreover, it can provide information to clinician or obstetrician for better management of these patients.

\section{Methods}

The present cross sectional study was carried out in the Department of Physiology, Sir Salimullah Medical College and Mitford Hospital, Dhaka, during the period of $1^{\text {st }}$ January 2009 to $31^{\text {st }}$ December 2009. A total number of 136 subjects were included in this study, and were divided into control $(n=82)$ and study $(n=54)$ groups. Of the control group, 28 were non pregnant women age ranged between 20-30 years, taken for reference value and another 54 were full term group, also treated as control, were subdivided into normal full term mother $(n=27)$ and their respective neonates $(n=27)$. Another 54 were preterm group, considered as study group, were sub-divided into preterm mothers $(\mathrm{n}=27)$ and their respective neonates $(n=27)$. Age ranged of preterm and full term mother were from 20-40 years. Protocol of this study was approved by the Institutional Ethics Committee (IEC) of SSMC. Subjects having history of any microbial and metabolic diseases were excluded from the study. All the subjects were belonged to lower socioeconomic status. The pregnant women were selected from labor ward of Sir Salimullah Medical College and Mitford Hospital and non pregnant women were from personal contact. After selection of the subjects, the objectives and benefits of the study were explained and written informed consent was taken from the subjects. All ethical norms were maintained. Institutional permission was taken from the Director of the Hospital. Detail personal, dietary, medical, family, socio-economic, occupational histories were taken and a thorough clinical examination was 
done and all informations were recorded in a standard prefixed questionnaire. With all aseptic precautions five (05) $\mathrm{ml}$ of maternal blood was drawn from medial cubital vein by disposable syringe and five (05) $\mathrm{ml}$ of neonatal blood was collected from placental end of cord immediately after delivery. After centrifugation of blood supernatant serum was collected in labeled eppendroff tube and was used for different biochemical tests. However, serum copper level was estimated by spectrophotometric method ${ }^{16}$ in the laboratory of Atomic Energy Commission, Dhaka, to observe its level in these groups of study subjects. Again, to observe the availability of $\mathrm{Cu}$-binding protein and nutritional status of the study subjects serum total protein and albumin levels were estimated by standard laboratory technique in the Department of Physiology, SSMC, Dhaka. Moreover, anthropometric data and blood hemoglobin level of the preterm and full term mother and birth weight of their respective neonates were measured to observe their nutritional status. Correlation of maternal serum copper concentration with that of neonatal blood and also with birth weight of the neonates were done to observe their relationships. The statistical analysis was done by Independent-samples " $\mathrm{t}$ " test and Pearson's correlation test by using SPSS, Version-15.

\section{Results}

The anthropometric data, along with mean $\mathrm{Cu}$, total protein, albumin, globulin and hemoglobin levels of non pregnant women were within normal range and were taken for reference value.

Anthropometric data of the subjects are presented in Table I.

This table shows that mean height $(p<0.01)$, weight $(p<0.001)$ and BMI $(p<0.001)$ were significantly lower in preterm mother in comparison to that full term mother.

Mean birth weight of preterm neonates was significantly $(\mathrm{p}<0.001)$ lower in comparison to those of full-term neonates (Figure 1).

Mean serum $\mathrm{Cu}$ level was significantly $(\mathrm{p}<0.001)$ lower in preterm mother than that of full term

Table I: Age, Height, Weight and BMI in different groups $(\mathrm{n}=82)$

\begin{tabular}{|c|c|c|c|c|}
\hline Groups & Age (year) & Height (meter) & Weight (kg) & $\operatorname{BMI}\left(\mathrm{kg} / \mathrm{m}^{2}\right)$ \\
\hline$A(n=28)$ & $20.50 \pm 0.64$ & $154.76 \pm 2.07$ & $57.50 \pm 2.59$ & $24.00 \pm 0.65$ \\
\hline$B_{1}(n=27)$ & $24.74 \pm 3.34$ & $156.63 \pm 2.17$ & $62.07 \pm 1.92$ & $25.30 \pm 0.63$ \\
\hline$C_{1}(n=27)$ & $23.37 \pm 3.98$ & $154.85 \pm 2.46$ & $56.22 \pm 4.29$ & $23.42 \pm 1.36$ \\
\hline \multicolumn{5}{|c|}{ Statistical analysis } \\
\hline & \multicolumn{4}{|c|}{$\mathrm{p}$ value } \\
\hline A vs B1 & $0.001 * * *$ & $0.002 * *$ & $0.001 * * *$ & $0.001 * * *$ \\
\hline A vs C1 & $0.001 * * *$ & $0.887^{\text {ns }}$ & $0.190^{\mathrm{ns}}$ & $0.056^{\mathrm{ns}}$ \\
\hline $\mathrm{B}_{1}$ vs $\mathrm{C}_{1}$ & $0.176^{\mathrm{ns}}$ & $0.007 * *$ & $0.001 * * *$ & $0.001 * * *$ \\
\hline
\end{tabular}

Data are expressed as Mean \pm SD. Statistical analysis was done by Independent -Samples “ $t$ ” test. Group A = Non-pregnant women Group- $\mathrm{B}_{1}=$ Full term group mother Group- $\mathrm{C}_{1}=$ Preterm mother

$\mathrm{n}=$ Total number of subjects.

ns $=$ Not significant. $* * *=\mathrm{p}<0.001 . * *=\mathrm{p}<0.01$. 


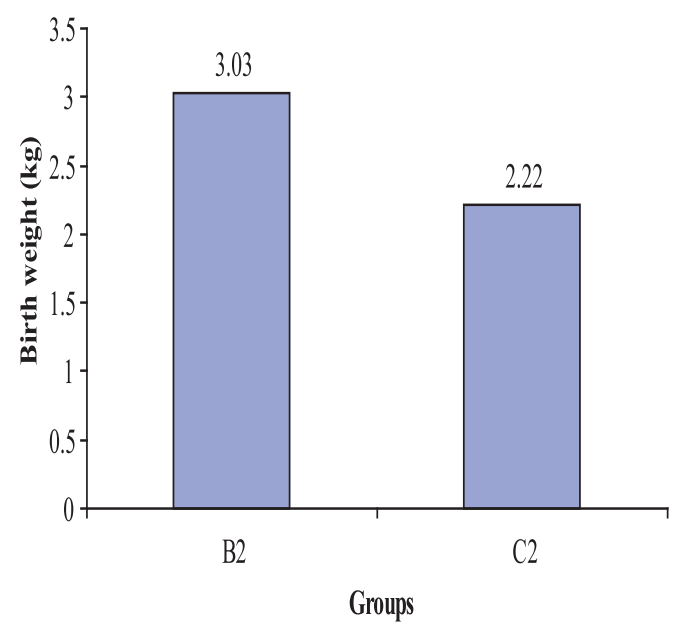

Figure 1: Mean birth weight of neonates $(n=54)$. Group $\mathrm{B}_{2}=$ Full term neonates, Group $\mathrm{C}_{2}=$ Preterm neonates mother and also in preterm neonates than that of full term neonates. Again, serum $\mathrm{Cu}$ level was significantly $(p<0.001)$ lower in full term and preterm neonates in comparison to that of their respective mother (Table II).

Mean serum total protein and albumin levels were significantly $(\mathrm{p}<0.001)$ lower in preterm mother than those of full term mother. Again, these values were significantly $(\mathrm{p}<0.001)$ lower in preterm neonates in comparison to those of full term neonates. On the other hand, mean serum globulin levels were almost similar and no statistically significant differences were observed among the groups (Table II).

Maternal serum copper concentrations showed negative correlation with that of neonatal blood, but positive correlation with birth weight of their respective neonates in both groups, though the reletionships were not statistically significant (Figure 2, 3).

Table II: Serum copper $(\mathrm{Cu})$, total protein, albumin, globulin and hemoglobin $(\mathrm{Hb})$ levels in different groups $(n=136)$

\begin{tabular}{|c|c|c|c|c|c|}
\hline Groups & $\mathrm{Cu}(\mu \mathrm{g} / \mathrm{dl})$ & Total Protein $(\mathrm{g} / \mathrm{dl})$ & $\operatorname{Albumin}(\mathrm{g} / \mathrm{dl})$ & Globulin(g/dl) & $\mathrm{Hb}((\mathrm{g} / \mathrm{dl})$ \\
\hline$A(n=28)$ & $120.89 \pm 17.7$ & $7.18 \pm 0.91$ & $4.79 \pm 0.88$ & $2.39 \pm 0.75$ & $11.16 \pm 0.80$ \\
\hline $\mathrm{B}_{1}(\mathrm{n}=27)$ & $186.00 \pm 50.45$ & $7.40 \pm 1.52$ & $4.81 \pm 1.14$ & $2.58 \pm 1.13$ & $8.89 \pm 0.65$ \\
\hline$B_{2}(n=27)$ & $56.56 \pm 22.96$ & $6.02 \pm 1.50$ & $4.10 \pm 1.14$ & $1.93 \pm 0.75$ & $\longrightarrow$ \\
\hline$C_{1}(n=27)$ & $115.90 \pm 22.03$ & $5.35 \pm 1.21$ & $3.10 \pm 0.98$ & $2.25 \pm 0.63$ & $9.36 \pm 0.34$ \\
\hline $\mathrm{C}_{2}(\mathrm{n}=27)$ & $38.26 \pm 8.28$ & $3.76 \pm 0.62$ & $1.98 \pm 0.50$ & $1.78 \pm 0.58$ & - \\
\hline \multicolumn{6}{|c|}{ Statistical analysis } \\
\hline \multicolumn{6}{|c|}{$P$ value } \\
\hline $\bar{A}$ vs B1 & $0.001 * * *$ & $0.528^{\mathrm{ns}}$ & $0.941^{\mathrm{ns}}$ & $0.536^{\mathrm{ns}}$ & $0.001 * * *$ \\
\hline A vs C1 & $0.357^{\mathrm{ns}}$ & $0.001 * * *$ & $0.001 * * *$ & $0.456^{\mathrm{ns}}$ & $0.001 * * *$ \\
\hline $\mathrm{B}_{1}$ vs $\mathrm{C}_{1}$ & $0.001 * * *$ & $0.001 * * *$ & $0.001 * * *$ & $0.272^{\mathrm{ns}}$ & $0.002 * *$ \\
\hline $\mathrm{B}_{1}$ vs $\mathrm{B}_{2}$ & $0.001 * * *$ & $0.002^{* *}$ & $0.030^{*}$ & $0.064^{\mathrm{ns}}$ & - \\
\hline $\mathrm{C}_{1} \mathrm{vs} \mathrm{C}_{2}$ & $0.001 * * *$ & $0.001 * * *$ & $0.001 * * *$ & $0.006^{* *}$ & - \\
\hline $\mathrm{B}_{2}$ vs C $_{2}$ & $0.001 * * *$ & $0.001 * * *$ & $0.001^{* * *}$ & $0.543^{\mathrm{ns}}$ & - \\
\hline
\end{tabular}

Data are expressed as Mean \pm SD. Statistical analysis was done by Independent-Samples “"”t" test.

Group A = non-pregnant women.

$\mathrm{B}_{1}=$ full term mother

$\mathrm{B}_{2}=$ full term neonates

$\mathrm{C}_{1}=$ preterm mother

$\mathrm{n}=$ number of subjects

$\mathrm{C}_{2}=$ preterm neonates

$* * *=\mathrm{p}<0.001 \quad *=\mathrm{p}<0.05 \quad * *=\mathrm{p}<0.01$

ns $=$ Not significant 


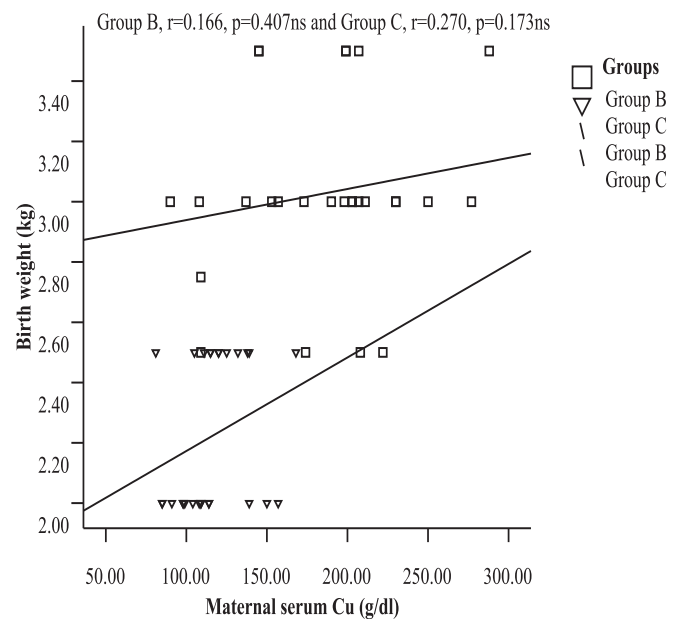

Figure 1: Correlation of maternal serum copper $(\mathrm{Cu})$ concentration with the birth weight of their neonates in both groups. Group $\mathrm{B}=$ full term group, Group $\mathrm{C}=$ pre term group, $\mathrm{B}_{1}=$ mother, $\mathrm{B}_{2}$ $=$ neonates. $\mathrm{C}_{1}=$ mother, $\mathrm{C}_{2}=$ neonate

\section{Discussion}

In this study mean $\mathrm{Cu}$, total protein, albumin, globulin and hemoglobin levels of non-pregnant women were within normal range and were taken as reference value.

In the present study hypocupremia have been observed both in preterm delivery mother and their neonates. Again, low birth weights have been documented in this group of neonates. These findings are consistent with those of some other researchers ${ }^{14}$. Pregnant women in developing countries consume diets with a lower quantity of protein, minerals and vitamins ${ }^{17}$. This inadequate dietary intake may be responsible for preterm delivery as well as for low birth weight of the neonates ${ }^{1}$.

It has been suggested that, elevated level of estrogen during pregnancy increases ceruloplasmin which in turn results in increased level of serum copper in full term mother ${ }^{18}$. Again, some other investigators suggested that nutritional deficiency or a metabolic defect along with decreased availability of $\mathrm{Cu}$-binding protein

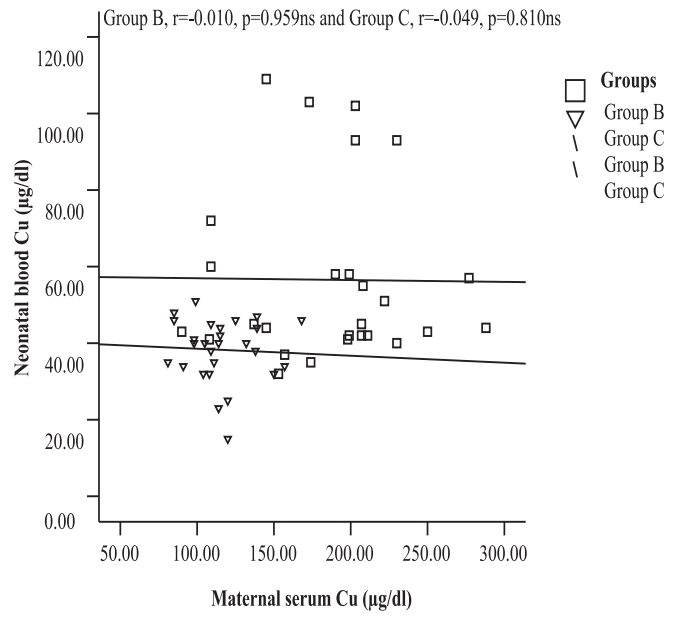

Figure 2: Correlation of maternal serum copper $\mathrm{Cu}$ concentration with that of neonatal blood in both groups. Group $\mathrm{B}=$ full term group, Group $\mathrm{C}=$ pre term group, $\mathrm{B}_{1}=$ mother, $\mathrm{B}_{2}=$ neonates, $\mathrm{C}_{1}$ $=$ mother, $\mathrm{C}_{2}=$ neonates

may result in hypocupremia during pregnancy, which may cause preterm delivery ${ }^{4,19}$. Moreover, hypocupremia may result from increased transfer of $\mathrm{Cu}$ from mother to fetus required for the fetal development ${ }^{4}$. However, some investigators suggested that, low maternal plasma copper concentration is closely associated with premature rupture of membrane ${ }^{19-21}$. Again, it has been observed that incidence of preterm delivery is fewer in women, receiving micronutrient supplementation during pregnancy $^{13}$.

Serum copper level may be lower in preterm neonates due to increased demand of this micronutrient for fetal growth, erythropoiesis and immaturity of the liver to synthesize ceruloplasmin $^{15}$.

However, poor socio-economic status of the study subjects indicates inadequate food intake especially low dietary protein as their hemoglobin level was lower. Again, low birth weight of preterm neonates in this study may be due to 
their hypocupremia, as evidenced by their measured values in cord blood. This hypocupremia of preterm neonates of present study may be due to diffusion of small fraction of maternal serum $\mathrm{Cu}$ through the placenta, as evidenced by the negative correlation of maternal serum $\mathrm{Cu}$ concentration with that of neonatal blood.

However, the exact mechanism involved for the preterm delivery and low birth weight of the neonates due to $\mathrm{Cu}$ deficiency cannot be elucidated from this type of study due to some limitation, such as short duration of the study period and small sample size.

\section{Conclusion}

From this study it can be concluded that, hypocupremia occur in preterm mother and their neonates may be due to poor nutritional status during pregnancy. This study also revealed that low serum $\mathrm{Cu}$ level may cause poor fetal outcome, as the preterm neonates had low birth weight. So, adequate intake of copper and protein enrich diet is necessary for some copper deficient pregnant women to prevent preterm delivery and for healthy fetal outcome

\section{Acknowledgement}

Authors of this study acknowledge the partial financial support from the research grant of DGHS of Bangladesh. The authors are also thankful to the study subjects for their active, sincere and voluntary participation.

\section{Author affiliations}

1. Masuda Sultana, Assistant Professor, Department of Physiology, Dhaka Community Medical College, Dhaka. Email: dr_masuda30@yahoo.comProfessor

2. Nasim Jahan, Professor \& Head, Department of Physiology, Sir Salimullah Medical College SSMC, Mitford, Dhaka. Email: prof.dr.nasimjahan (a)gmail.com

3. Nayma Sultana, Associate Professor, Department of Physiology, Sir Salimullah Medical College SSMC, Mitford, Dhaka. Email; nayma_sultana@yahoo.com

4. Rezina Akter, Associate Professor, Department of Physiology, Sir Salimullah Medical College SSMC, Mitford, Dhaka. Akter.rezina@yahoo.com

\section{References}

1. Abrams B, Newman V, Key T, Parker J. Maternal Weight Gain And Preterm Delivery. Obstet Gynecol. 1989; 74: 577-583.

2. Costello AM, Osrin D. Micronutrient Status During Pregnancy And Outcomes For Newborn Infants In Developing Countries. J Nutr 2003; 133: 1757S1764 S.

3. Walravens PA. Nutritional Importance Of Copper And Zinc In Neonates And Infants. Clin Chem. 1980; 26(2):185-189.

4. Perveen S, Altaf W, Vohra N, Bautista ML, Harper RG, Wapnir RA. Effect Of Gestational Age On Cord Blood Plasma Copper, Zinc, Magnesium And Albumin. Early Human Development 2002; 69:1523.

5. Keen CL, Hare JY, Hawk SN, Jankowski MA, Daston GP, Uribe CL, Rucker RB. Effect Of Copper Deficiency On Prenatal Development And Pregnancy Outcome. Am J Clin Nutr. 1998; 67(Suppl) : 1003S-1011S.

6. Olivares M, Hertramp E, Uauy R. Copper And Zinc Interactions In Anemia: A Public Health Perspective. In: Nutritional anemia. Sight and life press, 2007: 99-109. Available from: http:/ www.sightand life. org/SAL NutA/aa.html.

7. Iams JD. Prediction And Early Detection Of Preterm Labor. Obstet Gynecol. 2003; 101: 402412 .

8. Golub M, Gershwin ME, Hurley LS, Saito, Hendrickx AG. Studies On Marginal Zinc Deprivation In Rhesus Monkeys: IV. Growth Of Infants In The First Year Of Life. Am J Clin Nutr. 1984; 40: 1192-1202.

9. Beshgetoor D, Hambidge M. Clinical Conditions Altering Copper Metabolism In Humans. Am J Clin Nutr 1998; 67 (suppl): 1017S-1021S.

10. Bro S, Berendtsen H, Norgaard J, Host A, Jorgensen PJ. Serum Zinc And Copper Concentrations In Maternal And Umbilical Cord Blood. Relation To Course And Outcome Of Pregnancy. Sca J Clin Lab Invest 1988; 48: 805-811.

11. Hamer CJA, Kooten WJ, Boi J, Cornelisse C, Vermeulen AM. Copper And Zinc Values In Gynecology In Relation To Birth Weight. Nutr Res. 1985; 1(S): 285-288.

J Bangladesh Soc Physiol. 2012, June; 7(1): 41-47 
12. Scholl TO, Heliger ML, Scholl JI, Fischer RL, Khoo C. Low Zinc Intake During Pregnancy: Its Association With Preterm And Very Preterm Delivery. Am J Epi. 1993; 137(10): 1115-1124.

13. Upadhyaya C, Mishra S, Ajmera P, Sharma P. Serum Iron, Copper And Zinc Status In Maternal And Cord Blood. Ind J Clin Bio 2004; 19(2): 4852.

14. Atinmo T, Mbofung C, Osinusi BO. Relationship Of Zinc And Copper Concentrations In Maternal And Cord Blood And Birth Weight. J Gynaecol Obstet 1980:452-454.

15. Shaw JCL. Trace Elements In The Fetus And Young Infant. Am J Dis Child 1980;134: 74-81.

16. Smith JC, Butrimovitz GP. Direct Measurement Of Zinc And Copper In Plasma By Atomic Absorption Spectroscopy. Clin Chem. 1979;25(8): 1487-1491.

17. Mahan LK, Escott- Stump S. Nutrition During Pregnancy and Lactation. In: Krause's. Food,
Nutrition And Diet Therapy .Philadelphia :WB Saunders company;2004.p.183-189.

18. Solomons NW. On The Assessment Of Zinc And Copper Nutriture In Man. Am J Clin Nutr 1979; 32:856-871.

19. Artel R, Burgeson R, Fernandez FJ, Hobel CJ. Fetal And Maternal Copper Levels In Patients At Term With And Without Premature Rupture Of Membranes. Obstet Gynecol. 1979;53(5):608-610.

20. Kiiholma P, Gronroos M, Rkkola R, Pakarinen P, Nanto V. The Role Of Calcium, Copper, Iron, And Zinc In Preterm Delivery And Premature Rupture Of Foetal Membranes. Gynecol Obstet Invest 1984; 17: 194-201.

21. Wasowictz W, Wolkanin P, Bednarski M, Gromadzinska J, Sklodowska M, Grzybowska K. Plasma Trace Element ( $\mathrm{Se}, \mathrm{Zn}, \mathrm{Cu})$ Concentration In Maternal And Umbilical Cord Blood In Poland: Relation With Birth Weight, Gestation Age, Pariety. Bio Tra Ele Res. 1993; 38(2): 205-215. 